\title{
Luminescent bis-cyclometallated iridium(III) complexes containing phosphine-based ligands: influence of the $P^{\wedge} N$ bridge
}

Braulio S. Aranda, ${ }^{a}$ Pedro Aguirre, ${ }^{a}$ Sergio A. Moya, ${ }^{b}$ Mickaële Bonneau, ${ }^{\text {c,d }}$ J. A. Gareth Williams, ${ }^{\mathrm{d}}$ Loic Toupet, ${ }^{\mathrm{e}}$ Muriel Escadeillas, ${ }^{\mathrm{c}}$ Hubert Le Bozec, ${ }^{\mathrm{c}}$ Véronique Guerchais ${ }^{\mathrm{c}, *}$

${ }^{a}$ Universidad de Chile, Facultad de Ciencias Químicas y Farmacéuticas, Casilla 233, Santiago 1, Chile

${ }^{b}$ Universidad de Santiago de Chile, Facultad de Química y Biología, Av. Libertador Bernardo O'Higgins 3363, Casilla 40, Correo 33, Santiago, Chile

${ }^{c}$ Institut des Sciences Chimiques de Rennes, UMR CNRS-Université de Rennes 1 6226, Campus de Beaulieu, 35042 Rennes Cedex, France

${ }^{d}$ Department of Chemistry, Durham University, South Road, Durham, DH1 3LE, United Kingdom

${ }^{e}$ Institut de Physique de Rennes, UMR 6251 CNRS-Université de Rennes 1, Campus de Beaulieu, 35042 Rennes, France

* Corresponding author. Tel.: +332232367 29; fax: +33223236939.

E-mail address: veronique.guerchais@univ-rennes1.fr

ABSTRACT: Three cationic bis-cyclometallated iridium complexes $\left[\operatorname{Ir}\left(\mathrm{C}^{\wedge} \mathrm{N}\right.\right.$ ppyMe $\left.)_{2}\left(\mathrm{P}^{\wedge} \mathrm{N}\right)\right]\left[\mathrm{PF}_{6}\right](\mathbf{1 - 3})$ with 4-methyl-2-phenylpyridine (ppyMe) as the $\mathrm{C}^{\wedge} \mathrm{N}$ cyclometallated ligands and 8 -(diphenylphosphino)quinoline $\left(\mathrm{Ph}_{2} \mathrm{Pqn}, \mathbf{L}_{\mathbf{1}}\right), \quad 2$ (diphenylphosphinoamino)pyridine $\left(\mathrm{Ph}_{2} \mathrm{PNHpy}, \mathbf{L}_{2}\right)$ or 2-(diphenylphosphinoamino) pyrimidine $\left(\mathrm{Ph}_{2} \mathrm{PNHpym}, \mathbf{L}_{3}\right)$ as $\mathrm{P}^{\wedge} \mathrm{N}$-ligands, were prepared, and their crystal structures and photoluminescence were investigated. The substitution of an "aromatic $\mathrm{C}^{\mathrm{Ar}}$ " (of a quinolyl group) by an "NH" bridge between the phosphine and imine ligating units of the $\mathrm{P}^{\wedge} \mathrm{N}$ ligand dramatically changes the luminescence characteristics of the resulting complexes. The complexes 2-3 featuring the P-NH-N ligand emit in the blue region, whereas complex 1 incorporating the $\mathrm{P}-C^{A r}-\mathrm{N}$ unit displays orange photoluminescence.

Keywords: Iridium complexes. Bis-cyclometallated complexes. Phosphine ligands. Luminescence. Blue phosphors

\section{Introduction}

Homoleptic and heteroleptic cyclometallated Ir(III) complexes are well known to emit phosphorescence at ambient temperature with high quantum yield. Numerous examples of cationic complexes incorporating a combination of two cyclometallated ligands and one 
diimine (e.g. bipyridine, phenanthroline or their derivatives) have been reported and the influence of the substitution of the diimine ligand on the electronic excited states described [1]. The emission energy of such heteroleptic complexes is readily fine-tuned by changing the nature of the cyclometallated ligand $\mathrm{C}^{\wedge} \mathrm{N}$ and the diimine ligand. For example, blue and green-blue phosphorescent $\operatorname{Ir}(\mathrm{III})$ complexes have been reported. The commonly used approaches to widen the HOMO-LUMO gap and shift emission further to the blue are either the use of electron-withdrawing substituents such as $\mathrm{F}$ or $\mathrm{CF}_{3}$ in the metallated aryl ring, which lowers the HOMO, or the replacement of the pyridine moiety of the $\mathrm{C}^{\wedge} \mathrm{N}$ ligands by $\mathrm{N}$ heterocyclic rings such as pyrazoles and N-heterocyclic carbenes to raise the LUMO [2].

Another way to increase the energy gap is through the use of non-conjugated ancillary diarylphosphine chelates in place of the diimine [3]. Indeed, the $\pi$-accepting character of the $\mathrm{PAr}_{2}$ group is expected to increase the metal-to-ligand charge-transfer (MLCT) energy level resulting in blue-shifted emission. Thus, blue-shifts of the emission maxima have been obtained using neutral [4,5] or cationic [6] heteroleptic $\operatorname{Ir}(\mathrm{III})$ complexes combining $\mathrm{C}^{\wedge} \mathrm{N}$ ligands with either $\mathrm{P}^{\wedge} \mathrm{C}$ or $\mathrm{P}^{\wedge} \mathrm{N}$ chelates.

On the other hand, $\mathrm{P}^{\wedge} \mathrm{N}$ ligands such as 8 -(diphenylphosphino)quinoline $\left(\mathrm{Ph}_{2} \mathrm{Pqn}, \mathbf{L}_{\mathbf{1}}\right), 2$ (diphenylphosphinoamino)pyridine ( $\left.\mathrm{Ph}_{2} \mathrm{PNHpy}, \mathbf{L}_{2}\right)$ and 8-(diphenylphosphinoamino)pyrimidine $\left(\mathrm{Ph}_{2} \mathrm{PNHpym}, \mathbf{L}_{\mathbf{3}}\right)$ represent an interesting class of heterobidentate ligands that have been applied by some of us for the palladium catalyzed methoxy-carbonylation of olefins (Scheme 1) [7].

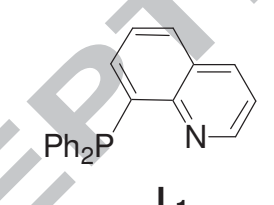

$\mathrm{L}_{1}$

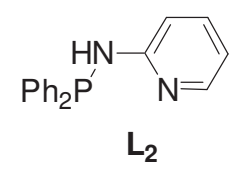

$\mathrm{L}_{2}$

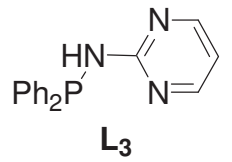

Scheme 1. Chemical structures of the $\mathrm{P}^{\wedge} \mathrm{N}$ ligands used in this study

Having in hand these chelating ligands, we sought to use them for the preparation of luminescent cationic $\operatorname{Ir}(\mathrm{III})$ complexes 1-3 (Scheme 2). Herein we report their synthesis and characterization, as well as their photophysical properties. We show that substitution of an "aromatic $\mathrm{C}^{\mathrm{Ar}}$ (of a quinolyl group) by an "NH" bridge between the phosphine and imine ligands of the $\mathrm{P}^{\wedge} \mathrm{N}$ ligand dramatically changes the luminescence characteristics of the resulting complexes. The complexes 2-3 featuring the $\mathrm{P}-\mathrm{NH}-\mathrm{N}$ ligands emit in the blue region, whereas the $\mathrm{P}-C^{A r}-\mathrm{N}$-incorporating complex 1 displays orange photoluminescence. 


\section{Experimental}

\subsection{Materials and general methods}

All manipulations were performed using Schlenk techniques under an Ar atmosphere, but the workups were carried out in air. All solvents were dried and purified by standard procedures. All starting materials were used as received. Complex $\left[\operatorname{Ir}\left(C^{\wedge} N-\mathrm{Meppy}\right)_{2}(\mu-\mathrm{Cl})\right]_{2}$ (Meppy $=4$-methyl-2-phenylpyridine) was prepared following the literature procedure [8]. The $\mathrm{P}^{\wedge} \mathrm{N}$ ligands, $\mathrm{Ph}_{2} \mathrm{Pqn}, \mathrm{Ph}_{2} \mathrm{PNHpy}$ and $\mathrm{Ph}_{2} \mathrm{PNHpym}$, were synthesized according to reported methods [7,9].

NMR spectra were recorded on Bruker Ascend 400, AV 300 or AV $500 \mathrm{MHz}$ spectrometers. UV-visible absorption spectra were recorded using an AnalitikJena Specord 205 spectrophotometer. High resolution mass spectra (HRMS) were performed on a MS/MS MicrO-Tof-Q 2 at the CRMPO (Centre de Mesures Physiques de l'Ouest) in Rennes. Elemental analyses were performed on a FlashEA1112 at the CRMPO.

Steady-state luminescence spectra were measured using a Jobin Yvon FluoroMax-2, fitted with a red-sensitive Hamamatsu R928 photomultiplier tube. The spectra shown are corrected for the wavelength dependence of the detector, and the quoted emission maxima refer to the values after correction. Phosphorescence lifetimes were measured by time-correlated singlephoton counting following excitation at $374 \mathrm{~nm}$ with an EPL-375 pulsed diode laser. The emitted light was detected at $90^{\circ}$ using a Peltier-cooled R928 PMT after passage through a monochromator. Spectra at $77 \mathrm{~K}$ were obtained with the sample loaded in a $4 \mathrm{~mm}$ o.d. quartz tube inside a quartz-walled Dewar filled with liquid nitrogen.

Single crystals for X-ray diffraction studies were grown by slow diffusion of pentane into a $\mathrm{CH}_{2} \mathrm{Cl}_{2}$ solution of complexes $\mathbf{1 - 3}$ at $20^{\circ} \mathrm{C}$. All measurements were made in the omega-scan technique on a CCD Sapphire 3 Xcalibur diffractometer (Agilent) with graphite monochromatized MoK $\alpha$ radiation. The data collection and refinement parameters are presented in Table 2. The structures were solved with SIR-97 [10] which reveals the nonhydrogen atoms of the molecules. The whole structures were refined by full-matrix leastsquare techniques on $F^{2}$, with hydrogens refined using the Riding mode. Structures were solved by Patterson or direct methods. The structures were completed by subsequent difference Fourier techniques and refined by full-matrix least squares on $F^{2}$ (SHELXL-97) with initial isotropic parameters [11]. Atomic scattering factors were taken from international Tables for X-ray crystallography. ORTEP views were realized with PLATON [12]. The crystal structures of 1, 2 and $\mathbf{3}$ have been deposited at the Cambridge Crystallographic Data 
Centre and allocated the deposition numbers CCDC-938912, CCDC-907692, and CCDC912857, respectively. These data can be obtained free of charge at www.cccdc.cam.ac.uk/conts/retrieving.html [or from Cambridge Crystallographic Data Centre, 12, Union Road, Cambridge CB2 1EZ; Fax: (internat.) +44-1223/336-033; e-mail: deposit@ccdc.cam.ac.uk].

\subsection{Preparation of complexes 1-3.}

General procedure. The chloride-bridged dimer $\left[\operatorname{Ir}\left(\mathrm{C}^{\wedge} \mathrm{N}-\mathrm{Meppy}\right)_{2}(\mu-\mathrm{Cl})\right]_{2}(257 \mathrm{mg}, 0.228$ mmol), and the appropriate $\mathrm{P}^{\wedge} \mathrm{N}$-ligand $\mathbf{L}$ (2.1 equiv), and $\mathrm{AgPF}_{6}(181 \mathrm{mg} 0.716 \mathrm{mmol})$ were suspended in dichloromethane $(15 \mathrm{~mL})$. The reaction mixture was stirred under argon for $16 \mathrm{~h}$ at room temperature. The solution was filtered and the solvent was removed and the product was washed with diethyl ether $(3 \times 10 \mathrm{~mL})$. Crystallization from a $\mathrm{CH}_{2} \mathrm{Cl}_{2} /$ diethyl ether mixture gave the expected compound as a powder

\section{Results and Discussion}

\subsection{Synthesis and characterization of Ir(III) complexes 1-3}

The three $\mathrm{P}^{\wedge} \mathrm{N}$ ligands were prepared following previously reported procedures $[7,9]$. The cationic complexes $\left[\operatorname{Ir}\left(\mathrm{C}^{\wedge} \mathrm{N}-\mathrm{ppyMe}\right)_{2}\left(\mathrm{P}^{\wedge} \mathrm{N}\right)\right]\left[\mathrm{PF}_{6}\right](\mathbf{1 - 3})$ are readily accessible by treatment of the chloro-bridged dimer $\left[\operatorname{Ir}\left(\mathrm{C}^{\wedge} \mathrm{N}-\mathrm{Meppy}\right)_{2}(\mu-\mathrm{Cl})\right]_{2}$ with 2 equivalents of the appropriate $\mathrm{P}^{\wedge} \mathrm{N}$ ligand in the presence of excess $\mathrm{AgPF}_{6}$ to facilitate the removal of the chloride ligands. The $\mathrm{AgPF}_{6}$ also ensures that the complexes are isolated as their hexafluorophosphate salts, which offer better solubility over the chloride salts. All complexes are isolated in good yield after recrystallisation from $\mathrm{CH}_{2} \mathrm{Cl}_{2}$ /diethyl ether. They were fully characterized by standard spectroscopic methods $\left({ }^{1} \mathrm{H}\right.$ and ${ }^{31} \mathrm{P}$ NMR $)$ and gave satisfactory analysis. In the ${ }^{31} \mathrm{P}\left\{{ }^{1} \mathrm{H}\right\} \mathrm{NMR}$ spectrum of $1\left(\mathrm{CD}_{2} \mathrm{Cl}_{2}\right)$, the coordinated phosphine gives rise to a singlet at $\delta 8.20 \mathrm{ppm}$, which is shifted to higher field in comparison with that of the free ligand $\mathbf{L}_{\mathbf{1}}\left(\delta\left(\mathrm{CHCl}_{3}\right)=-\right.$ $14.20 \mathrm{ppm})$.

Complex 1: yellow-green powder (55\% yield). ${ }^{1} \mathrm{H}$ NMR $\left(400 \mathrm{MHz}, \mathrm{CD}_{2} \mathrm{Cl}_{2}\right): 8.60(\mathrm{~d}, 1 \mathrm{H}$, $\left.{ }^{3} J=8.4 \mathrm{~Hz}\right), 8.50-8.46(\mathrm{~m}, 2 \mathrm{H}), 8.37\left(\mathrm{~d}, 1 \mathrm{H},{ }^{3} J=8.0 \mathrm{~Hz}\right), 8.05\left(\mathrm{t}, 1 \mathrm{H},{ }^{3} J=7.6 \mathrm{~Hz}\right), 7.83-7.76$ $(\mathrm{m}, 5 \mathrm{H})$, 7.59-7.55 (m, 1H), 7.50-7.41 (m, 4H), $7.31(\mathrm{~s}, 1 \mathrm{H})$, 7.15-7.10 (m, 2H), 7.05-6.95 (m, $4 \mathrm{H}), 6.86\left(\mathrm{td}, 2 \mathrm{H},{ }^{3} J=6.5 \mathrm{~Hz},{ }^{4} J=2.3 \mathrm{~Hz}\right), 6.59\left(\mathrm{~d}, 1 \mathrm{H},{ }^{3} J=7.2 \mathrm{~Hz}\right), 6.46\left(\mathrm{~d}, 1 \mathrm{H},{ }^{3} J=5.8\right.$ $\mathrm{Hz}), 6.36-6.32(\mathrm{~m}, 3 \mathrm{H}), 6.22\left(\mathrm{td}, 1 \mathrm{H},{ }^{3} J=6.0 \mathrm{~Hz},{ }^{4} J=2.0 \mathrm{~Hz}\right), 2.32(\mathrm{~s}, 3 \mathrm{H}), 2.27(\mathrm{~s}, 3 \mathrm{H})$. ${ }^{31} \mathrm{P}\left\{{ }^{1} \mathrm{H}\right\}$ NMR (162 MHz, $\left.\mathrm{CD}_{2} \mathrm{Cl}_{2}\right): 8.2$ (s), -145.0 (q, $\mathrm{PF}_{6}$ ). HRMS $\mathrm{m} / \mathrm{z}$ calcd. for 
$\mathrm{C}_{45} \mathrm{H}_{36} \mathrm{~N}_{3} \mathrm{P}^{193} \mathrm{Ir}: 842.22708$, found : 842.2270. Anal. Calcd for $\mathrm{C}_{45} \mathrm{H}_{36} \mathrm{~N}_{3} \mathrm{~F}_{6} \mathrm{P}_{2} \mathrm{Ir} 1.5 \mathrm{CH}_{2} \mathrm{Cl}_{2}: \mathrm{C}$, 50.12, H, 3.53, N, 3.77. Found C, 50.25, H, 3.35, N, 3.76.

Complex 2: yellow powder (75\% yield). ${ }^{1} \mathrm{H}$ NMR $\left(400 \mathrm{MHz}, \mathrm{CD}_{2} \mathrm{Cl}_{2}\right): 8.11\left(\mathrm{~d}, 1 \mathrm{H},{ }^{3} J=6.0\right.$ $\mathrm{Hz}), 7.92\left(\mathrm{~d}, 1 \mathrm{H},{ }^{3} \mathrm{~J}=3.4 \mathrm{~Hz}\right), 7.82-7.66(\mathrm{~m}, 6 \mathrm{H}), 7.54-7.44(\mathrm{~m}, 5 \mathrm{H}), 7.30(\mathrm{~s}, 1 \mathrm{H}), 7.28(\mathrm{~d}$, $\left.1 \mathrm{H},{ }^{3} J=6.0 \mathrm{~Hz}\right), 7.11-6.92(\mathrm{~m}, 7 \mathrm{H}), 6.71\left(\mathrm{t}, 2 \mathrm{H},{ }^{3} \mathrm{~J}=9.2 \mathrm{~Hz}\right), 6.62-6.56(\mathrm{~m}, 3 \mathrm{H}), 6.52(\mathrm{dd}$, $\left.1 \mathrm{H},{ }^{3} J=5.8 \mathrm{~Hz},{ }^{4} J=1.3 \mathrm{~Hz}\right), 6.19\left(\mathrm{t}, 1 \mathrm{H},{ }^{3} J=5.9 \mathrm{~Hz}\right), 2.45(\mathrm{~s}, 3 \mathrm{H}), 2.35(\mathrm{~s}, 3 \mathrm{H}) .{ }^{31} \mathrm{P}\left\{{ }^{1} \mathrm{H}\right\}$ NMR (162 MHz, $\mathrm{CD}_{2} \mathrm{Cl}_{2}$ ): 48.0 (s), -145.0 (q, $\mathrm{PF}_{6}$ ). HRMS m/z calcd. for $\mathrm{C}_{41} \mathrm{H}_{35} \mathrm{~N}_{4} \mathrm{P}^{193} \mathrm{Ir}$ : 807.22233, found: 807.2227. Anal. Calcd for $\mathrm{C}_{41} \mathrm{H}_{35} \mathrm{~N}_{4} \mathrm{~F}_{6} \mathrm{P}_{2} \mathrm{Ir}$ : C, 51.73, H, 3.71, N, 5.89. Found C, 51.87, H, 3.78, N, 5.75.

Complex 3: yellow green powder (70\% yield). ${ }^{1} \mathrm{H} \mathrm{NMR}\left(400 \mathrm{MHz}, \mathrm{CD}_{2} \mathrm{Cl}_{2}\right): 8.60(\mathrm{~s}, 1 \mathrm{H})$, $8.11\left(\mathrm{~d}, 1 \mathrm{H},{ }^{3} J=6.0 \mathrm{~Hz}\right), 7.78(\mathrm{~s}, 1 \mathrm{H}), 7.75-7.67(\mathrm{~m}, 5 \mathrm{H}), 7.59\left(\mathrm{t}, 1 \mathrm{H},{ }^{3} J=7.1 \mathrm{~Hz}\right), 7.54-7.49$ $(\mathrm{m}, 3 \mathrm{H}), 7.40\left(\mathrm{~d}, 1 \mathrm{H},{ }^{3} \mathrm{~J}=6.0 \mathrm{~Hz}\right), 7.32(\mathrm{~s}, 1 \mathrm{H}), 7.18-7.08(\mathrm{~m}, 2 \mathrm{H}), 7.06-6.94(\mathrm{~m}, 5 \mathrm{H}), 6.78-$ $6.70(\mathrm{~m}, 4 \mathrm{H}), 6.59-6.55(\mathrm{~m}, 2 \mathrm{H}), 6.20\left(\mathrm{t}, 1 \mathrm{H},{ }^{3} \mathrm{~J}=6.1 \mathrm{~Hz}\right), 2.39(\mathrm{~s}, 3 \mathrm{H}), 2.29(\mathrm{~s}, 3 \mathrm{H}) .{ }^{31} \mathrm{P}\left\{{ }^{1} \mathrm{H}\right\}$ NMR (162 MHz, $\mathrm{CD}_{2} \mathrm{Cl}_{2}$ ): 39.1 (s), -145.0 (q, $\mathrm{PF}_{6}$ ). HRMS $\mathrm{m} / z$ calcd. for $\mathrm{C}_{40} \mathrm{H}_{34} \mathrm{~N}_{5} \mathrm{P}^{193} \mathrm{Ir}$ : 808.21758, found: 808.2177. Anal. Calcd for $\mathrm{C}_{40} \mathrm{H}_{34} \mathrm{~N}_{5} \mathrm{~F}_{6} \mathrm{P}_{2} \mathrm{Ir}$ : C, 50.42, H, 3.60, N, 7.35. Found C, 49.92, H, 3.46, N, 7.13.

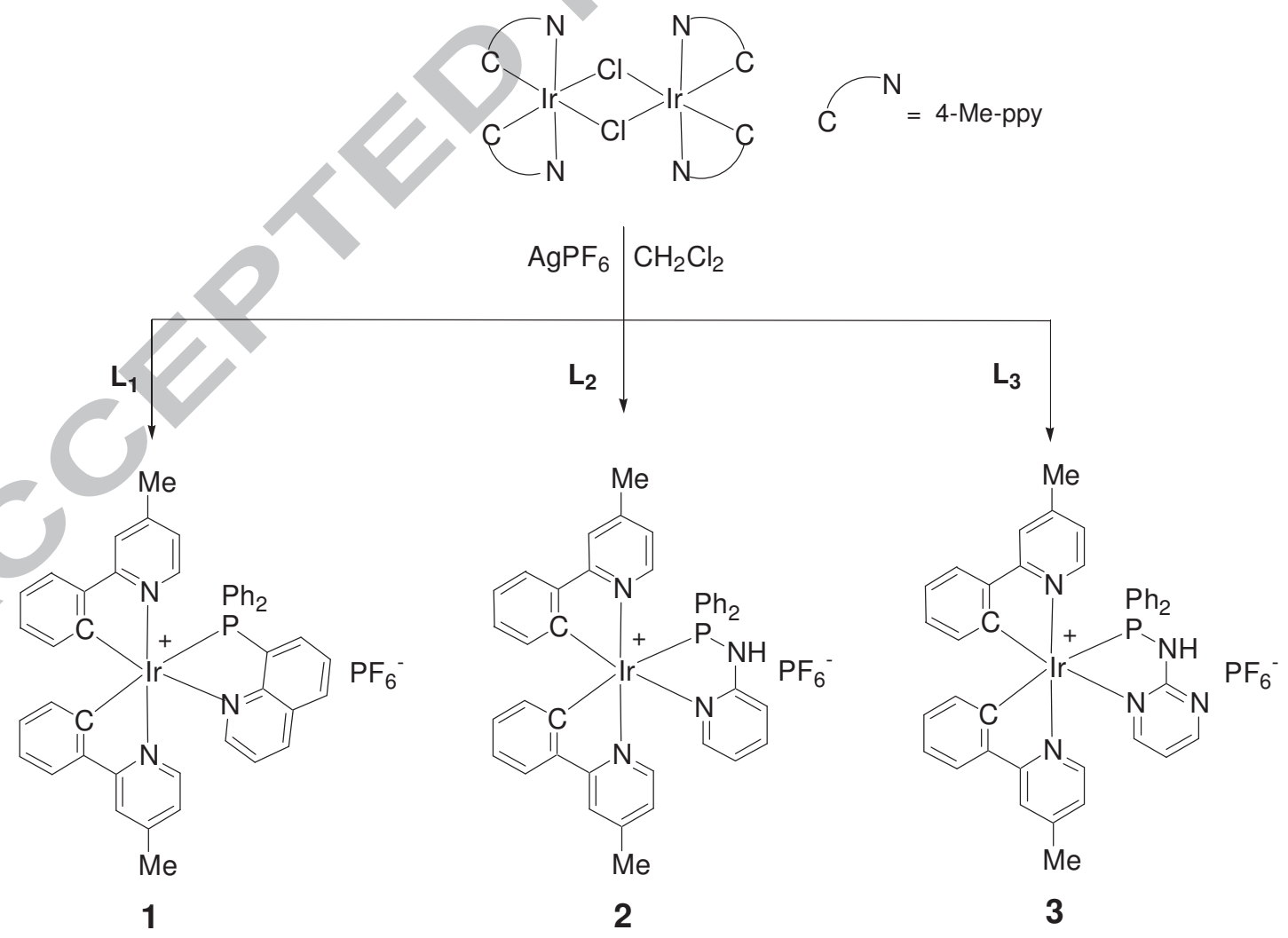




\section{Scheme 2}

\subsection{X-Ray structures}

The structures of the three complexes 1-3 were confirmed by X-ray crystal structure analyses, as shown in Figure 1. Selected bond length and bond angle data are listed in Tables 1 and 2. All complexes reveal a distorted octahedral geometry around iridium, consisting of two cyclometallated $\mathrm{C}^{\wedge} \mathrm{N}$ ligands and one $\mathrm{P}^{\wedge} \mathrm{N}$ ligand with the phosphorus atom being trans to a cyclometallated carbon atom. The ligand arrangement, where the two Ir-C bonds are in mutually cis positions, is similar to that of the parent phenylpyridine ligands in many heteroleptic $\operatorname{Ir}(\mathrm{III})$ complexes such as the diketonate complex $\operatorname{Ir}\left(\mathrm{C}^{\wedge} \mathrm{N}-\mathrm{ppy}\right)_{2}\left(\mathrm{O}^{\wedge} \mathrm{O}-\mathrm{acac}\right)[13]$ and the cationic bipyridine derivatives [8]. The N-Ir and C-Ir bond distances involving the cyclometallated ligand are in the same range as those reported for related Ir complexes [14]. The Ir-N3 bond distances (where N3 is the coordinated nitrogen atom of the $\mathrm{P}^{\wedge} \mathrm{N}$ ligand in each case) are longer than those the coordinated Meppy ligand. In the three complexes, both the Ir-N3 and the Ir-P bond lengths of the $\mathrm{P}^{\wedge} \mathrm{N}$ ligand are very similar.. The chelate bite angle of the phosphine ligand $\left(\sim 80^{\circ}\right)$ is the same for each complex. For the $\mathrm{PPh}_{2} \mathrm{Pqn}$-containing complex, the deviations of atoms Irl and P1 from the least-square quinolyl ring plane are only 0.214 and $0.033 \AA$, respectively. These latter values are comparable to those found in other iridium(III) complexes [15]. They indicate that the chelate coordination of $\mathrm{Ph}_{2} \mathrm{Pqn}$ forms a strain-free planar five-membered ring.

Table 1

Selected bond lengths $(\AA)$ for complexes 1-3.

\begin{tabular}{llll}
\hline Bond & $\mathbf{1}$ & $\mathbf{2}$ & $\mathbf{3}$ \\
\hline Ir-C1 & $2.055(3)$ & $2.013(6)$ & $2.029(4)$ \\
Ir-C13 & $2.017(3)$ & $2.051(4)$ & $2.054(5)$ \\
Ir-N1 & $2.069(3)$ & $2.052(3)$ & $2.041(4)$ \\
Ir-N2 & $2.040(3)$ & $2.067(4)$ & $2.057(4)$ \\
Ir-N3 & $2.173(3)$ & $2.192(4)$ & $2.180(4)$ \\
Ir-P1 & $2.3404(9)$ & $2.3412(11)$ & $2.3143(12)$ \\
P1-NH & & $1.696(4)$ & $1.700(4)$ \\
P1-CPh & & $1.814(4)$ & $1.802(5)$
\end{tabular}


a)

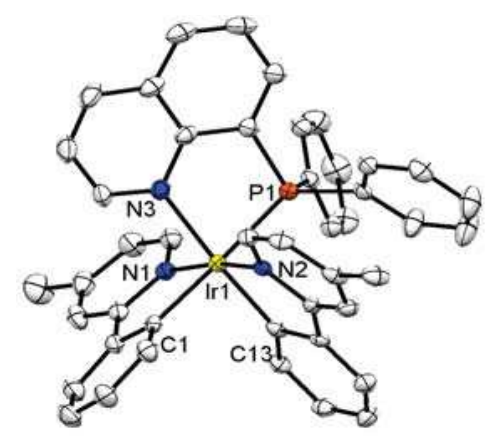

b)

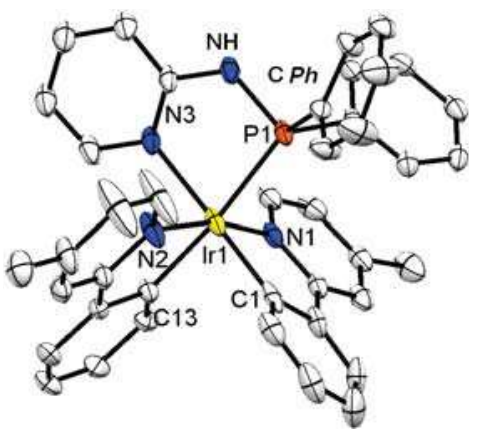

c)

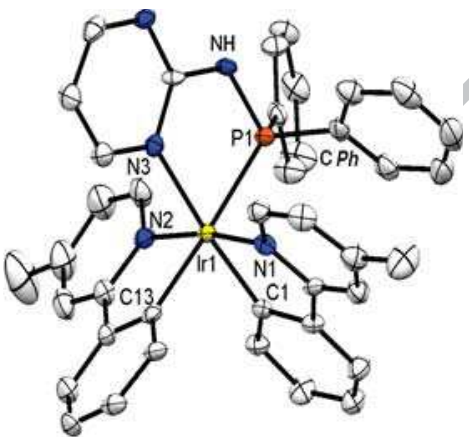

Fig.1. ORTEP drawing displaying the molecular structure of complexes 1(a), 2 (b) and 3(c) with ellipsoids at the $50 \%$ probability level. Hydrogen atoms are omitted for clarity.

Table 2

Selected bond angles $\left(^{\circ}\right)$ for complexes 1-3.

\begin{tabular}{cccc}
\hline Bond & $\mathbf{1}$ & $\mathbf{2}$ & $\mathbf{3}$ \\
\hline C1-Ir-C13 & $86.70(12)$ & $86.02(17)$ & $88.55(17)$ \\
C1-Ir-N1 & $79.49(12)$ & $79.79(17)$ & $80.38(17)$ \\
C1-Ir-N2 & $91.76(12)$ & $167.38(16)$ & $80.38(17)$ \\
C1-Ir-N3 & $95.96(11)$ & $179.06(15)$ & $174.88(16)$ \\
C1-Ir-P1 & $177.40(9)$ & $101.43(12)$ & $95.10(13)$ \\
C13-Ir-N1 & $96.68(11)$ & $89.79(15)$ & $93.11(18)$ \\
C13-Ir-N2 & $79.97(11)$ & $79.76(16)$ & $78.91(18)$ \\
C13-Ir-N3 & $174.61(11)$ & $93.05(16)$ & $95.87(15)$ \\
C13-Ir-P1 & $95.56(9)$ & $172.09(13)$ & $176.29(12)$ \\
N1-Ir-N2 & $170.84(11)$ & $167.38(16)$ & $171.22(15)$ \\
N1-Ir-N3 & $88.42(10)$ & $100.26(15)$ & $96.76(15)$ \\
N1-Ir-P1 & $101.49(8)$ & $88.91(10)$ & $86.87(11)$ \\
N2-Ir-N3 & $95.24(10)$ & $87.44(18)$ & $87.77(15)$ \\
N2-Ir-P1 & $87.37(7)$ & $102.40(11)$ & $101.34(11)$ \\
N3-Ir-P1 & $81.69(8)$ & $79.51(10)$ & $80.45(10)$ \\
NH-P1-CPh & & $104.6(2)$ & $104.9(2)$ \\
\hline
\end{tabular}




\subsection{Electronic absorption and luminescence properties}

The UV-vis absorption data of complexes 1-3 in $\mathrm{CH}_{2} \mathrm{Cl}_{2}$ are summarized in Table 3, and the corresponding spectra are shown in Figure 2. The absorption spectra of complexes 1-3 show intense absorption bands in the higher energy region $(\lambda<340 \mathrm{~nm})$ which are dominated by intra-ligand ${ }^{1} \mathrm{IL}\left(\pi \rightarrow \pi^{*}\right)$ transitions of the $\mathrm{C}^{\wedge} \mathrm{N}$ and $\mathrm{P}^{\wedge} \mathrm{N}$ ligands, and a moderately intense lower-energy absorption band at longer wavelength (around $360 \mathrm{~nm}$ ) assigned to the tail of the IL transitions overlapping with MLCT $\mathrm{d} \pi(\operatorname{Ir}) \rightarrow \pi^{*}\left(\mathrm{C}^{\wedge} \mathrm{N}\right.$ and $\left.\mathrm{P}^{\wedge} \mathrm{N}\right)$ transitions. The spectrum of complex $\mathbf{1}$ has a weak shoulder extending to longer wavelengths than for $\mathbf{2}$ and $\mathbf{3}$, possibly reflecting the more extended $\pi$-conjugation of the chelated quinolylphosphine ligand. The spectra of $\mathbf{2}$ and $\mathbf{3}$ are very similar to those reported for the related complex $\left[\operatorname{Ir}\left(\mathrm{C}^{\wedge} \mathrm{N}-\mathrm{ppy}\right)\left(\mathrm{P}^{\wedge} \mathrm{N}-\mathrm{dppmp}\right)\right]\left[\mathrm{PF}_{6}\right]$ having a $\mathrm{P}^{\wedge} \mathrm{N}$-2-diphenylphosphinomethylpyridine (dppmp) ligand, which contains a saturated " $\mathrm{CH}_{2}$ " bridge instead of $\mathrm{NH}$ [6].

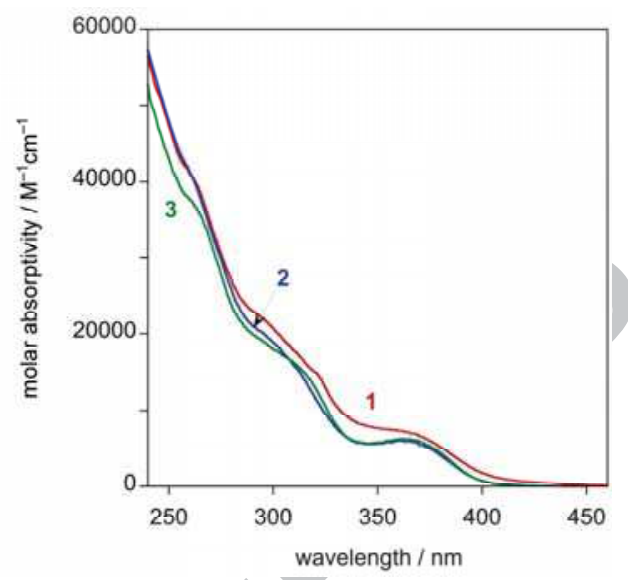

Fig 2. UV-Vis absorption spectra $\left(\mathrm{CH}_{2} \mathrm{Cl}_{2}, 298 \mathrm{~K}\right)$ for complexes 1-3.

\section{Table 3}

Photophysical data of the investigated iridium(III) complexes.

\begin{tabular}{|c|c|c|c|c|c|}
\hline Cpd & $\begin{array}{c}\lambda_{\text {abs }} / \mathbf{n m} \\
\left(\varepsilon\left[\mathbf{M}^{-1} \mathbf{c m}^{-1}\right]\right)^{[\mathrm{a}]}\end{array}$ & $\lambda_{\mathrm{em}} / \mathbf{n m}^{[\mathrm{b}, \mathrm{c}]}$ & $\tau / \mathbf{n s}$ & $\lambda_{\text {em }}$ at $77 \mathrm{~K} / \mathrm{nm}^{[\mathrm{c}, \mathrm{d}]}$ & $\Phi[\%]^{[\mathrm{e}]}$ \\
\hline 1 & $\begin{array}{l}\text { 293sh (22300) } 359 \\
(7130)\end{array}$ & 580 & 1800 & $500,530,567$ & 7.5 \\
\hline 2 & $\begin{array}{l}296(20100), 361 \\
(5920)\end{array}$ & $461,491,522$ & 270 & $458,481,512$ & 0.68 \\
\hline 3 & $\begin{array}{l}\text { 306sh (16800), } 362 \\
(6270)\end{array}$ & $460,493,526$ & 30 & $458,481,512$ & 0.04 \\
\hline
\end{tabular}

[a] Values refer to solutions in $\mathrm{CH}_{2} \mathrm{Cl}_{2}$ at $298 \mathrm{~K}$, except where indicated otherwise. [b] In degassed $\mathrm{CH}_{2} \mathrm{Cl}_{2}$ solutions. [c] $\lambda_{\text {exc }}=365 \mathrm{~nm}$. [d] In EPA [e] $\mathrm{Ru}(\mathrm{bpy})_{3} \mathrm{Cl}_{2}$ was used as the standard $(\Phi=0.028$ in air-equilibrated water). 
Upon irradiation, complexes 1-3 are photoluminescent in $\mathrm{CH}_{2} \mathrm{Cl}_{2}$ solution at $298 \mathrm{~K}$ but they display very different emission characteristics depending on the nature of the $\mathrm{P}^{\wedge} \mathrm{N}$ ligand. The luminescence data are listed in Table 3 and the emission spectra are shown in Figure 3. Complex 1 displays a broad emission band centred in the orange region of the spectrum at $590 \mathrm{~nm}$ with a lifetime of $1800 \mathrm{~ns}$. The emission is red-shifted compared to related wellknown complexes such as $\operatorname{Ir}\left(\mathrm{C}^{\wedge} \mathrm{N}-\mathrm{ppy}\right)_{2}\left(\mathrm{O}^{\wedge} \mathrm{O}\right.$-acac $)$ which may be a reflection of a lowerlying LUMO, localised on the quinolyl group of the $\mathrm{P}^{\wedge} \mathrm{N}$ ligand as opposed to the pyridyl of the $\mathrm{C}^{\wedge} \mathrm{N}$ ligands. Complexes $\mathbf{2}$ and $\mathbf{3}$, on the other hand, emit in the blue spectral region, and the spectra display well-resolved structure. The breaking of the conjugation of the $\mathrm{P}^{\wedge} \mathrm{N}$ bridge has an essential impact in determining the nature of the emissive state. The blue emission could be attributed to the $\pi$ accepting properties of the phosphorus, lowering the energy of the metal-based orbitals that contribute to the HOMO, whilst the LUMO remains localised on the pyridyl rings of the

$\mathrm{C}^{\wedge} \mathrm{N}$ ligands.

a)

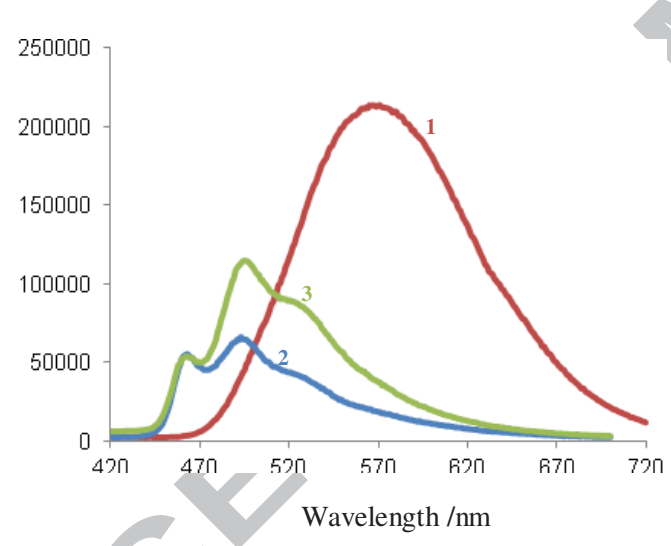

b)

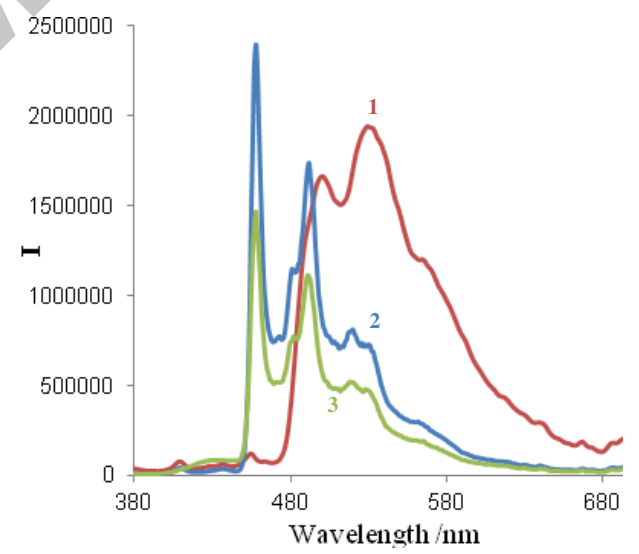

Fig.3 Emission spectra of complexes 1-3 $\left(\lambda_{\text {ex }}=365 \mathrm{~nm}\right.$ ): (a) in $\mathrm{CH}_{2} \mathrm{Cl}_{2}$ at $298 \mathrm{~K}$ ), (b) in EPA, at $77 \mathrm{~K}$.

As has frequently been found in other studies aimed at blue emitters, the quantum yield falls off and the lifetimes shorten on moving to the blue region, possibly due to quenching of the emissive state through close-lying d-d states. Replacement of a pyridine by a pyrimidine ring in $\mathbf{3}$ has little influence on the emission maxima, but it is striking that the lifetime decreases by an order of magnitude. This could be due to a greater degree of distortion in the excited state of $\mathbf{3}$. Indeed, close inspection of the spectra of $\mathbf{2}$ and $\mathbf{3}$ reveals that, although the 
wavelengths of the emission maxima coincide, the relative intensity of the $0-0$ vibrational band in the spectrum of $\mathbf{3}$ is substantially smaller than for $\mathbf{2}$, consistent with a larger degree of excited state distortion in the former. At $77 \mathrm{~K}$, on the other hand, such distortion will be impeded, and indeed the spectra of the two complexes under these conditions are essentially identical.

The significant variation of emission wavelength between the use of "conjugated" and "non-conjugated" ligand $\mathrm{P}^{\wedge} \mathrm{N}$ ligand has been previously reported. For instance, when diphenylnaphtylphosphine (dpn) is used as ancillary ligand in $\operatorname{Ir}(\mathrm{III})$ complexes $\left[\left(\mathrm{C}^{\wedge} \mathrm{N}\right.\right.$ Fppy $)_{2} \operatorname{Ir}(\mathrm{dpn})$ ] [16], a broad emission in the orange region is observed $\left(-580-630 \mathrm{~nm}\right.$ for $\mathrm{C}^{\wedge} \mathrm{N}$ (FppyH $=2$-(2,4-difluorophenyl)pyridine) whereas the benzyl analogue [4a,b] gives rise to blue-emitting species.

\section{Concluding remarks}

Three cationic bis-cyclometallated iridium complexes with 4-methyl-2-phenylpyridine (Meppy) as the $\mathrm{C}^{\wedge} \mathrm{N}$-cyclometallated ligands and the $\mathrm{P}^{\wedge} \mathrm{N}$-ligands, 2-(diphenylphosphino) quinoline $\left(\mathrm{Ph}_{2} \mathrm{Pqn}, \mathbf{L}_{\mathbf{1}}\right)$, 2-(diphenylphosphinoamino)pyridine $\left(\mathrm{Ph}_{2} \mathrm{PNHpy}, \mathbf{L}_{2}\right)$ and 2(diphenylphosphinoamino) pyrimidine $\left(\mathrm{Ph}_{2} \mathrm{PNHpym}, \mathbf{L}_{\mathbf{3}}\right)$, were prepared, and their $\mathrm{X}$-ray crystallography and photoluminescence were investigated. The above results demonstrate that phosphine derivatives, ubiquitous molecules used in catalysis, are also interesting ligands for the elaboration of luminescent metal complexes. Moreover, an efficient method to tune the color of the emission involves changing the degree of conjugation in these ancillary chelate ligands. Thus, we showed that the use of "non-conjugated" and $\pi$ accepting phosphorus-based species as ancillary ligands allows the emission of cationic heteroleptic $\operatorname{Ir}(\mathrm{III})$ complexes to be shifted to the blue region.

\section{Acknowledgements}

This work was supported by LIA CNRS 836 Chili (MIF) and Fondecyt (\# 1120149). B.A gratefully acknowledges the French Embassy in Chile for a grant. M.B. thanks the CNRS and Durham University for a joint PhD studentship.

\section{References}


[1] (a) Y. You, W. Nam, Chem. Soc. Rev. 41 (2012) 7061-7084.

(b) S. Ladouceur, E. Zysman-Colman, Eur. J. Inorg. Chem. (2013) 2985-3007.

(c) C. Ulbricht, B. Beyer, C.Friebe, A. Winter, U. S. Schubert, Adv. Mater. 21 (2009) 4418-4441.

[2] To date, a large number of blue emissive iridium complexes has been reported. See inter alia:

(a) C. Adachi, M. A. Baldo, S. R. Forrest, M. E. Thompson, Appl. Phys. Lett.77 (2000) 904-906;

(b) S. Stagni, S. Colella, A. Palazzi, G. Valenti, S. Zacchini, F. Paolucci, M. Marcaccio, R.

Q. Albuquerque, L. De Cola, Inorg. Chem. 47 (2008) 10509-10521;

(c) S. J. Lee, K.-M. Park, K.Yang, Y. Kang, Inorg. Chem. 48 (2009) 1030-1037;

(d) J. M. Fernandez-Hernandez, J. I. Beltran, V. Lemaur, M.-D. Galvez-Lopez, C.-H. Chien, F. Polo, E. Orselli, R. Frolich, J. Cornil, L. de Cola, Inorg. Chem. 52 (2013) 18121824 ;

(e) Y.-H. Song, Y.-C. Chiu,Y. Chi, Y.-M. Cheng, C.-H. Lai, P.-T. Chou, K.-T.Wong, M.-

H. Tsai, C.-C. Wu, Chem. Eur. J. 14 (2008) 5423-5434;

(f) M. Ashizawa, L. Yang, K. Kobayashi, H. Sato, A. Yamagishi, F. Okuda, T. Harada, R. Kuroda, M. Haga, Dalton Trans. (2009) 1700-1702;

(g) H. Oh, K.-M. Park, H. Hwang, S. Oh, J. H. Lee, J.-S. Lu, S. Wang, Y. Kang, Organometallics 32 (2013) 6427-6436;

(h) L. He, L. Duan, J. Qiao, R. Wang, P. Wei, L. Wang, Y. Qiu, Adv. Funct. Mater. 18 (2008) 2123-2131;

(i) T. Sajoto, P. I. Djurovich, A. Tamayo, M. Yousufuddin, R. Bau, M. E. Thompson, R. J. Holmes, S. R. Forrest, Inorg. Chem. 44 (2005) 7992-8003;

(j) C.-F. Chang, Y.-M. Cheng, Y. Chi, Y.-C. Chiu, C.-C. Lin, G.-H. Lee, P.-T. Chou, C.-C. Chen, C.-H. Chang, C.-C. Wu, Angew. Chem. Int. Ed. 47 (2008) 4542-4545.

[3] Y, Chi, P.-T. Chou, Chem. Soc. Rev. 39 (2010) 638-655.

[4] (a) J.-Y. Hung, Y. Chi, I-H. Pai, Y.-C. Yu, G.-H. Lee, P.-T. Chou, K.-T. Wong, C.-C.

Chen, C.-C. Wu, Dalton Trans. (2009) 6472-6475;

(b) Y.-C. Chiu, C.-H. Lin, J.-Y. Hung, Y. Chi, Y.-M. Cheng, K.-W. Wang, M.-W. Chung,

G.-H. Lee, P.-T. Chou, Inorg. Chem. 48 (2009) 8164-8172;

(c) C.-H. Lin, Y.-Y. Chang, J.-Y. Hung, C.-Y. Lin, Y. Chi, M.-W. Chung, C.-L. Lin, P.-T. Chou, G.-H. Lee, C.-H. Chang, W.-C. Lin, Angew. Chem. Int. Ed. 50 (2011) 3182-3186; 
(d) S. A. Moore, D. L. Davies, M. M. Karim, J. K. Nagle, M. O. Wolf, B. O. Patrick, Dalton Trans. 42 (2013) 12354-12363.

[5] Y.-C. Chiu, Y. Chi, J.-H. Hung, Y.-M. Cheng, Y.-C. Yu, M.-W. Chung, G.-H. Lee, P.-T. Chou, C.-C. Chen, C.-C. Wu, H.-Y. Hsieh, ACS Appl. Mater. Interfaces 1 (2009) 433-442.

[6] A.-F. Ma, H.-J. Seo, S.-H. Jin, U.C. Yoon, M.H. Hyun, S.K. Kang, Y.-I. Kim, Bull. Korean Chem. Soc. 30 (2009) 2754-2578.

[7] P.A. Aguirre, C.A. Lagos, S.A. Moya, C. Zuniga, C. Vera-Oyarce, E. Sola, G. Peris, J.C Bayon, Dalton Trans. (2007) 5419-5426.

[8] M. Lepeltier, T.K.-M. Lee, K. W.-W. Lo, L. Toupet, H. Le Bozec, V. Guerchais, Eur. J. Inorg. Chem. (2005) 110-117.

[9] S.M. Aucott, A.M.Z. Slawin, J.D. Woolins, J. Chem. Soc. Dalton Trans. (2000) 25592575.

[10] R. A. J. Binstead and A. D. Zuberbulher, Specfit/32 Global analysis system, Spectrum Software Associates, Chapel Hill NC, 2000.

[11] A. Altomare, M. C. Burla, M. Camalli, G.Cascarano, C. Giacovazzo, A. Guagliardi, A. G. G. Moliterni, G. Polidori and R. Spagna, Sir97: a new tool for crystal structure determination and refinement J. Appl. Crystallogr., 31 (1998) 74-77.

[12] G. M. Sheldrick, SHELX97-2 Program for Crystal Structure Refinement; Göttingen, Germany. 1997. International Tables for X-ray Crystallography Vol. C. Ed. Wilson, A. J. C.

[13] S. Lamansky, P. Djurovich, D. Murphy, F. Abdel-Razzaq, H.- E. Lee, C. Adachi, P. E. Burrows, S. R. Forrest, M. E. Thompson, J. Am. Chem. Soc. 123 (2001) 4304-4312.

[14] For examples of X-ray crystal structures of ( $C^{\wedge} N$-ppy) $\operatorname{Ir}(\mathrm{III})$ complexes, see inter alia:

(a) F. Neve, A. Crispini, Eur. J. Inorg. Chem. (2000) 1039-1043;

(b) K. K. Lo, J. S. Chan, C. Chung, V. W. Tsang, N. Zhu, Inorg. Chim. Acta 357 (2004) 3109-3118;

(c) F. Neve, M. La Deda, A. Crispini, A. Belluci, F. Punterio, S. Campagna, Organometallics 23 (2004) 5856-5863 ;

(d) J. Li, P. I. Djurovich, B. D. Alleyne, M. Yousufuddin, N. N. Ho, J. C. Thomas, J. C. Peters, R. Bau, M. E. Thompson, Inorg. Chem. 44 (2005) 1713-1727;

(e) N. Zao, Y.-H. Wu, H.-M. Wen, X. Zhang, Z.-N. Chen, Organometallics 28 (2009) 5603-5611. 
[15] For examples of X-ray crystal structures of $\operatorname{Ir}(\mathrm{III})$ complexes containing the $\mathrm{Ph}_{2} \mathrm{Pqn}$ ligand, see inter alia: T. Suzuki, M. Kotera, A. Takayama, M. Kojima, Polyhedron 28 (2009) 2287-2293. S. Michlik, R. Kempe, Chem. Eur. J. 16 (2010) 13193-13198.

[16] B.-S. Du, C.-H. Lin, Y. Chi, J.-Y Hung, M.-W. Chung, T.-Y. Lin, G.-H. Lee, K.-T. Wong, P.-T. Chou, W.-Y. Hung, H.-C. Chiu, Inorg. Chem. 49 (2010) 8713-8723.

\section{Graphical abstract}

Three cationic bis-cyclometallated iridium complexes with 4-methyl-2-phenylpyridine (Meppy) as the $\mathrm{C}^{\wedge} \mathrm{N}$-cyclometallated ligands and the $\mathrm{P}^{\wedge} \mathrm{N}$-ligands, 8(diphenylphosphino)quinoline $\left(\mathrm{Ph}_{2} \mathrm{Pqn}, \quad \mathbf{L}_{\mathbf{1}}\right), \quad$ 2-(diphenylphosphinoamino)pyridine $\left(\mathrm{Ph}_{2} \mathrm{PNHpy}, \mathbf{L}_{\mathbf{2}}\right)$ and 2-(diphenylphosphinoamino)pyrimidine $\left(\mathrm{Ph}_{2} \mathrm{PNHpym}, \mathbf{L}_{\mathbf{3}}\right)$, were prepared, and their X-ray crystallography, and photoluminescence were investigated. The complexes 2-3 featuring the $P-\mathrm{NH}-N$ ligands emit in the blue region, whereas the $P-\mathrm{C}^{\mathrm{Ar}}-N-$ incorporating complex $\mathbf{1}$ displays orange photoluminescence.

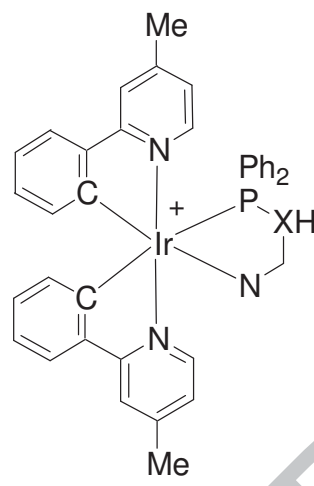<smiles>Pc1cccc2cccnc12</smiles><smiles>PNc1ccccn1</smiles>
$\mathbf{L}_{2}$<smiles>PNc1ncccn1</smiles>
$\mathrm{L}_{3}$

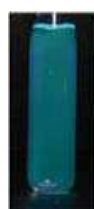

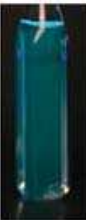


a)

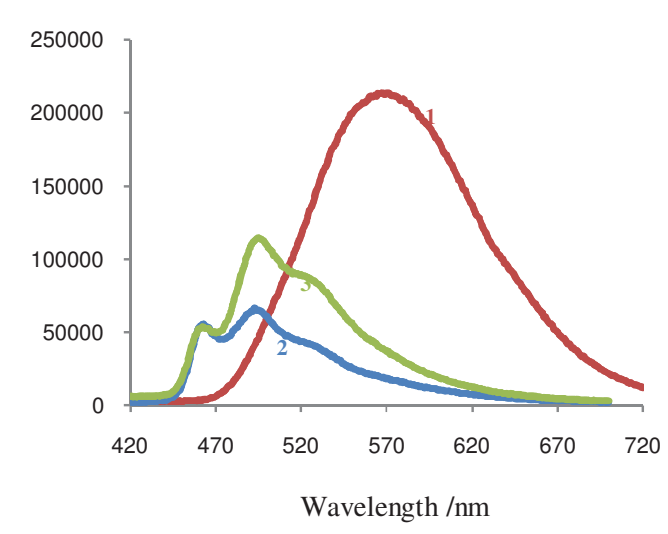

b)

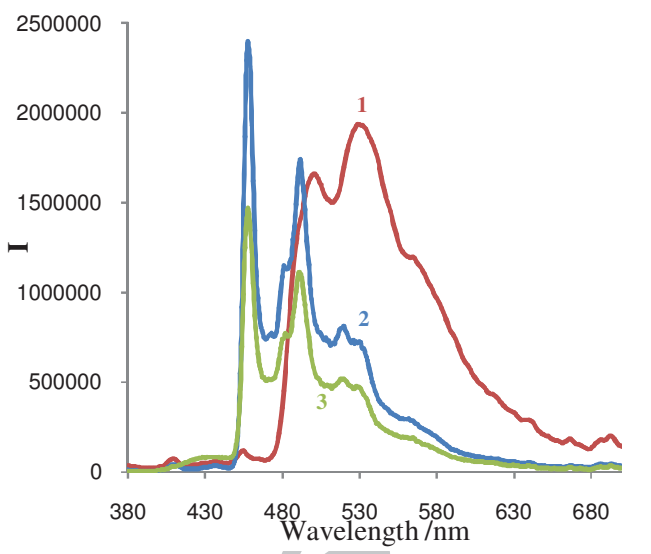

Fig.3 Emission spectra of complexes 1-3 $\left(\lambda_{\text {ex }}=365 \mathrm{~nm}\right.$ ): (a) in $\mathrm{CH}_{2} \mathrm{Cl}_{2}$ at $298 \mathrm{~K}$ ), (b) in EPA, at $77 \mathrm{~K}$. 